\title{
The Family as a Context for Religious and Spiritual Development in Children and Youth
}

Chris J. Boyatzis

David C. Dollahite

Brigham Young University, david_dollahite@byu.edu

Loren D. Marks

Brigham Young University - Provo, loren_marks@byu.edu

Follow this and additional works at: https://scholarsarchive.byu.edu/facpub

Part of the Other Social and Behavioral Sciences Commons

\section{Original Publication Citation}

Boyatzis, C., Dollahite, D. C., \& Marks, L. D. (2006). The family as a context for religious and spiritual development in children and youth. In E. C. Roehlkepartain, P. E. King, L. Wagener, \& P. L. Benson (Eds.), The handbook of spiritual development in childhood and adolescence (pp. 297-309). Thousand Oaks, CA: Sage.

\section{BYU ScholarsArchive Citation}

Boyatzis, Chris J.; Dollahite, David C.; and Marks, Loren D., "The Family as a Context for Religious and Spiritual Development in Children and Youth" (2006). Faculty Publications. 4897.

https://scholarsarchive.byu.edu/facpub/4897

This Book Chapter is brought to you for free and open access by BYU ScholarsArchive. It has been accepted for inclusion in Faculty Publications by an authorized administrator of BYU ScholarsArchive. For more information, please contact ellen_amatangelo@byu.edu. 


\title{
21
}

\section{ThE FAMILY AS A}

\section{CONTEXT FOR RELIGIOUS}

\section{and Spiritual DeVElopment IN ChILDREN AND YouTH}

\author{
Chris J. BOYATZIS \\ David C. Dollahite \\ LOREN D. MARKS
}

$\mathrm{O}$ ur chapter addresses how the family promotes or hinders transcendence of the self in children, that is, how the family is a context in which spiritual development occurs. Due to space limitations, our emphasis is on socialization and interaction processes within the family and not on other issues such as psychodynamic processes (e.g., Rizzuto, 1979) or faith development (e.g., Fowler, 1981). There are many motivations to explore family socialization of religious and spiritual development. One, family spirituality and religiosity are linked with many desirable outcomes and inversely with negative outcomes in children and youth. (Other chapters in this volume examine these issues.) Two, therapists and family life educators are increasingly addressing spirituality and religion (Richards \& Bergin, 1997). Three, religion is an important, even central force in many families (Dollahite, Marks, \& Goodman, 2004).
In America, religion is in some ways a family affair, as $95 \%$ of married couples and parents report a religious affiliation (Mahoney, Pargament, Swank, \& Tarakeshwar, 2001), and about 90\% of parents desire religious training for their children (Gallup \& Castelli, 1989). Thus, the widespread significance of religion to so many families compels scholars to examine the family as a locus of religious and spiritual development (RSD). Although religion (and spirituality) has been examined by sociology (e.g., Durkheim, 1897/1986) and psychology (e.g., James, 1902/1896) for more than a century, these disciplines have only recently begun to address RSD in connection with family. (In contrast, organized religions have a long tradition of emphasizing the family as the crucial context for RSD; e.g., Bunge, 2001.)

Family scholars exploring spirituality have frequently described it as a type of transcendence 
that can involve going beyond the limits of materiality and the physical tendencies of humanity (Bahr \& Bahr, 1996). Anderson and Worthen (1997) suggest that "every human relational event can be viewed as spiritual" (p. 5), and we believe this is particularly true for intergenerational family relationships. Spirituality permeates human relationships and is often, though not necessarily, associated with religious belief and practice. Spiritual and religious development are similar though distinct processes that often influence each other, and most people are concerned about both at some level (Miller \& Thoresen, 2003); for this reason, we will often alternate between these terms. At the outset, we encourage family scholars to investigate how families themselves define and conceptualize spirituality.

\section{FAMILY AND RELIGIOUS AND SPIRItUAl DeVElopment}

In this section, we highlight topics that illuminate RSD of youth and children in the family: (a) religion and family in America; (b) family interaction and parent-child communication; (c) models of religious and spiritual influence in families; (d) narrative epistemology and ritual in family life; (e) the role of mothers, fathers, and siblings in children's religious growth; (f) conservative Protestant parenting; and (g) unhealthy spirituality in families.

\section{Religion and Family in America}

The majority of data in this chapter are drawn from U.S. samples. We unfortunately know much less about religion and family in non-Western faiths and cultures-in other words, about most of the families of the earthas well as non-Christian families in America (see Boyatzis, 2003). We recognize that our focus on the nuclear family is a limitation but this is due in large part to the focus by researchers on the nuclear family.

Recent empirical studies report positive connections between parents' religiosity and higher parental warmth (Bartkowski \& Wilcox, 2000), closer parent-child relationships (Dollahite et al., 2004; Mahoney et al., 2001), and different aspects of parent functioning (Brody, Stoneman, \& Flor, 1996; Gunnoe, Hetherington, \& Reiss, 1999). Further, parental religiosity is associated positively with various desirable child outcomes and inversely with negative outcomes (Mahoney et al., 2001) and protects adolescents (Brody et al., 1996; Regnerus, 2003). In sum, family religiosity is a positive factor in development, though it can also be an unhealthy force in families, which we address later.

Even if it takes a village to raise a child, the family is surely "the first village" of RSD. Parents' practices and beliefs constitute a personal religious community (Cornwall, 1987), and the family functions as "interpreters of religious ideology" (Heller, 1986, p. 32). On many measures, particularly behavioral indicators such as worship attendance, children's religiosity appears consistent with their parents' religiosity (e.g., Acock \& Bengston, 1978; Bao, Whitbeck, Hoyt, \& Conger, 1999; Dudley \& Dudley, 1986; Hoge, Petrillo, \& Smith, 1982; King, Furrow, \& Roth, 2002). The pressing question concerns how the family influences spiritual development.

\section{Family Interaction and Parent-Child Communication}

It is likely that parents influence their children's RSD as they do other realms, that is, through verbal communication and induction and indoctrination of beliefs, disciplinary tactics, rewards and punishments, and behavioral modeling. "Spiritual modeling" and spiritual observational learning are important mechanisms (Bandura, 2003; Silberman, 2003). For example, work from England has underscored the power of parental modeling of specific behaviors such as praying in children (Francis \& Brown, 1990) and adolescents (Francis \& Brown, 1991). Families also engage in activities that can promote children's RSD, such as saying rote mealtime prayers, engaging in devotions at home, and performing religiously motivated charity for others. Retrospective reports from religious adults confirm that these kinds of "embedded routines"-regular family ritualswere frequent in their families in childhood and helped form the narrative structure of religious meaning in family life (Wuthnow, 1999). 
Dollahite and Marks (2005) created a conceptual model from narrative analyses of indepth interviews conducted in the homes of 74 highly religious Jewish, Christian, Mormon, and Muslim families from various regions in the United States. The framework suggests the contexts, processes, and outcomes at work in highly religious families as they strive to fulfill the sacred purposes suggested by their faith—chief among them passing on religious and spiritual meaning and practice to their children. Dollahite and Marks identified 10 central processes families used to facilitate RSD among family members, including: relying on God or God's word for support and guidance; sanctifying the family by living religion at home, including religious traditions; resolving conflict with prayer, repentance, and forgiveness; loving and serving others in the family, faith community, and wider community; overcoming challenges and trials through shared faith; abstaining from proscribed activities and substances; sacrificing time, money, comfort, and convenience for religious/ spiritual reasons; nurturing spiritual observance and growth in family members through teaching, example, and discussion; obeying God, prophets, parents, or commandments; and putting faith or family ahead of personal or secular interests. Narratives from children and youth (ages 10-20) indicated, for example, that religiously inspired service to people in the faith community and wider community allowed children and youth to develop positive qualities: greater concern and empathy for others; abstention from proscribed activities and substances and making sacrifices for religious/spiritual reasons, which encouraged youth to develop ego strength and a sense of uniqueness through being different from their peers; and a religiously motivated emphasis on honoring their parents, which fostered more respect and less contention between youth and parents. Children and youth indicated that their spiritual development was facilitated primarily through their parents' teaching, example, and through parent-child discussions of spiritual/religious issues (often initiated through children's questions and concerns). Although this sample consisted of highly religious families, this study identifies religious and spiritual socialization processes that may operate in many families.
Another study has examined parent-child discussion about religion. Boyatzis and Janicki (2003) asked a small sample of Christian families with children ages 3 to 12 to complete a survey on parent-child communication and keep a diary of all conversations about religious and spiritual issues. In diaries, God was discussed in one out of two conversations. Data from surveys and diaries demonstrated that in such conversations children are active: They initiate and terminate about half of family conversations about religion, they speak as much as parents do, and they ask questions and offer their own views. Parents asked many more open-ended questions than test questions (e.g., "What do you think heaven is like?" vs. "Who built the Ark?"). In this study, parents did not impose their own beliefs too strongly. One measure was a "conviction rating," as parents indicated on a 5-point scale in each diary the degree to which their comments reflected their actual beliefs about the topic. The average rating was 3.7, suggesting that parents were not strongly stating their own views, or that parents "watered down" their statements to help their children better understand their views. (Another interpretation is that parents were not sure of their own beliefs.) The diary and survey data support the notion that most families' conversations about religion have a mutual give-and-take with reciprocal influence. This is consistent with two different but compatible models.

\section{Models of Religious and Spiritual Influence in Families}

A sociocultural model emphasizes the role of knowledgeable adults who use scaffolding and guided participation in culturally meaningful practices to help the child move to higher understandings (Vygotsky, 1978). Thus, parents have the important task of helping children maneuver toward higher competencies in their zone of proximal development. A second model, consistent with but building on the first, is a transactional model of development that posits that children and parents influence each other $(\mathrm{P} \leftarrow \rightarrow \mathrm{C})$ in recurrent reciprocal exchanges (Kuczynski, 2003). This characterization of family interaction contrasts sharply with a unilateral $\mathrm{P} \rightarrow \mathrm{C}$ "transmission" model that has 
dominated socialization research for decades. Bidirectional transactional models differ from the unilateral transmission model in key ways (Kuczynski, 2003). First, transmission models assume a static asymmetry of power between parent and child; in transactional models, there is an interdependent asymmetry. Transactional models presume that causes and effects are recursive and indeterminate, so it is difficult to determine when parent influence ends and child influence begins. Inherent in this view is that child $\rightarrow$ parent influence occurs, but unfortunately few scholars have examined this dynamic. It is likely (see Boyatzis, 2004) that in some families there is a distinct "parent as mentor, child as apprentice" role structure; in other families, there may be more fluidity between these roles as parent and child can function as teacher and student to the other. Finally, in some families the child may be viewed as something of a "spiritual savant" with full spiritual status. This perspective seems common in many indigenous cultures (e.g., the Beng of West Africa, the Warlpiri Aboriginals of north-central Australia), which view babies as having recently come to the living from a realm of ancestral spirits (see DeLoache \& Gottlieb, 2000); this view is shared to some extent in Latter-day Saint (Mormon) doctrine, which posits that children exist in spirit form prior to birth, and newborns come to a family immediately and directly from being in the presence of God (Dollahite, 2003). We mention these different parent-child roles and views of children to expand our conceptions of the child's spiritual place in the family.

Research must address the degree to which parent-child communication actually influences children's and parents' spiritual growth. Although Boyatzis and Janicki (2003) did not measure this impact, in other studies sustained discourse on religion between parents and adolescents strongly related to how the adolescents felt about religion, whereas poor communication inhibited transmission of beliefs and values (Flor \& Knapp, 2001). Adults' retrospective reports suggest that religious views were shaped by conversations about religion in childhood (e.g., Dudley \& Wisbey, 2000; Wuthnow, 1999). A longitudinal study on adolescents' moral reasoning found that moral reasoning was enhanced when parents asked questions about the child's opinions and discussed the child's reasoning (Walker \& Taylor, 1991). Research on other topics reveals that parents' speech influences children's maturity. For example, the more parents use words when talking with their toddlers that describe mental states (e.g., think, believe, wonder), the more the children later use such mental-state terms when they are preschoolers (Jenkins, Turrell, Kogushi, Lollis, \& Ross, 2003). Do such patterns emerge in family discourse about religious or spiritual issues?

Parents and children have distinct conversational styles (e.g., Beaumont, 2000). Parents know that some children have a high tolerance for ambiguity, and their spirituality may grow best in a milieu of ongoing open-ended exchanges that prioritize questions and ruminations over answers and certainty. Other children prefer closure and may find the didactic transmission of information most helpful. Does growing up with a particular family communication style predict specific religious beliefs and faith orientations later in life? Are communication styles in childhood nascent forms of religious orientations that continue into adulthood? Longitudinal work is needed to answer these questions, but it is likely that family discourse about religious and spiritual issues creates a milieu in which children construct spiritual meaning and understanding. Parents' views can serve as cognitive anchors (Ozorak, 1989) for children's beliefs, and the reciprocal dynamic in conversation allows parent and child to coconstruct meaning (Boyatzis, 2004).

Given the role that such communication might have, would there be stronger correspondence or independence between children's and parents' religious and spiritual beliefs? The correspondence position is that children's beliefs would be strongly similar to their parents' beliefs; we might expect this given the ample evidence of similarity between children's and parents' religiosity (e.g., Acock \& Bengston, 1978; Bao et al., 1999). However, these studies have focused on religious behavior more than beliefs and attitudes, and in some studies there is greater correspondence between parent and child religious behavior than belief (e.g., Francis \& Gibson, 1993), though in some cases, as in a study of Conservative Jewish families 
(Parker \& Gaier, 1980), there is strong similarity in religious belief as well. In general, we might also expect considerable independence between parent and child beliefs because it has become a truism in developmental and cognitive psychology (see Johnson \& Boyatzis, chapter 15, this volume) that children actively construct their reality. While many studies show that both correspondence and independence occur (see Boyatzis, in press), the image of the child as an active creator of his or her own spiritual belief is most illuminating theoretically because it challenges the venerable (and limited) model of oneway $\mathrm{P} \rightarrow \mathrm{C}$ transmission of belief.

Consider work by Evans (2000), who analyzed beliefs about the origins of species and the world in children growing up in families that were either distinctly secular or Christian fundamentalist. Evans found that 7- to 9-yearold children from both family types-fundamentalist and secular-were likely to have Creationist views of the origin of species and view the natural world as the product of a nonhuman supernatural being. Not until early adolescence did youth in secular homes begin to embrace their families' evolutionist views. Important evidence is emerging that children's religious belief is less related to their parents' (self-reported) beliefs than to the children's perceptions of the parents' religious views (e.g., Bao et al., 1999; Okagaki \& Bevis, 1999). Thus, what parents do and believe may matter less than what children think parents do and believe. Studies of family socialization must account for children's intuitive belief systems and active construction of input around them.

\section{Narrative Epistemology and Ritual in Family Life}

Narrative is a fundamental epistemology for humans, and family narratives are a major embodiment of meaning. One reason why religions are so prevalent as worldviews is that they offer descriptive, explanatory stories about their adherents' place in the world and in relation to each other and to a transcendent divinity. Indeed, religious narratives map onto human thinking naturally, particularly with children, as story plays a central role in children's thinking (see Johnson \& Boyatzis, chapter 15, this volume). Even though family-centered data have emerged over the past decades, the majority of studies have used survey data. Although valuable, such data paint broad but often shallow images that fail to capture the human capacity and need for narrative. Narrative is at the heart of familial and personal meaning making, and hence it is integral to spirituality/religion. For example, a recent narrative-based study (Dollahite \& Clifton, 2005) of 45 adolescents from highly religious Jewish, Christian, and Muslim families indicated that religion offered and promoted a sense of purpose and direction, stronger connections to family and others, a unique identity as a religious person, and enhancement of confidence. The adolescents also offered rich illustrations and explanations of the interface between religious and family life, which would be difficult to tap with quantitative methods.

Narrative methods can also provide scholars with firsthand accounts of what it is like to be raised with spiritual or religious expectations and experiences as well as be a parent trying to facilitate a child's or adolescent's spiritual development in a culture or circumstance that makes that difficult. However, few researchers have examined personal and family narratives as a way of understanding spirituality and religion.

Another topic requiring attention is children's enactment and understanding of ritual. Ritual is an integral feature in many world religions and has an important place in family traditions. Some questions researchers could address include these: How are Jewish children affected by their central role in opening the Passover seder? How do Muslim children experience their obligation to pray to Allah five times a day? How are children in sacramental Christian traditions affected by first communion or confirmation? These kinds of issues are at the heart of faith traditions and social scientists should address them.

In a recent study of the influence of sacred rituals in families, Marks (2004) offers qualitative reports from parents regarding why sacred practices and rituals are influential and meaningful to Christian, Jewish, and Muslim parents. Parents indicated several motivations for family rituals, including a desire "to transmit religious beliefs of parents to children," consistent with 
the traditional view of socialization discussed previously. Two other parental motivations were to "teach" and "provide an example" for their children. These findings indicate that parents may be influenced to influence their children; thus, a transactional influence seems to occur. A final motivation for sacred ritual was that less eager parents reported engaging in sacred rituals because their children "push or pull them into it" (Marks, 2004, p. 221). This is the type of "bottom-up," child $\rightarrow$ parent influence that has been rarely captured in the past. Unfortunately, this study did not include views from children or adolescents in the family. Anecdotal data speak to the import of family rituals in childhood (Wuthnow, 1999), but systematic research should describe the form, frequency, meaning, and influence of children's religious rituals.

\section{The Role of Mothers, Fathers, and Siblings}

Within the family, many individuals have the potential to affect and be affected by children's religious and spiritual growth. Based on research, it is axiomatic to say that in most families the mother is the primary figure in children's religiosity. This finding has emerged in the United States (e.g., Acock \& Bengston, 1978; Okagaki \& Bevis, 1999; Strommen \& Hardel, 2000), England (Francis \& Gibson, 1993), and Australia (Hunsberger \& Brown, 1984), and the mother's prominence has been confirmed in Jewish intermarriages (Silberman, 1985) and other religious groups (Brodsky, 2000). Even in interfaith families, children's denominational affiliation is more similar to the mothers' than the fathers' (Nelsen, 1990), especially when the mother is Catholic.

Why do mothers have such an influential role, and what mechanisms are at work? Women are more religious than men and attend worship services more often (e.g., Spilka, Hood, Hunsberger, \& Gorsuch, 2003), and adults recall seeing their mothers pray more than their fathers did (Wuthnow, 1999). In general, mothers speak with their children more than fathers do (e.g., Leaper, Anderson, \& Sanders, 1998) and in conversations about religion mothers are much more involved than fathers are. In one study using a diary method, mothers participated in all diary conversations in almost $90 \%$ of families, whereas fathers did not appear in any diary entries in almost half of the families (Boyatzis \& Janicki, 2003). In a national study, 3,000 mainline Protestant youth reported they had regular dialogue about faith issues with their mothers almost 2.5 times more often than with their fathers (Benson \& Eklin, 1990).

Mothers talk about emotions more than fathers do (e.g., Kuebli, Butler, \& Fivush, 1995) and, perhaps consequently, most children rate their mothers higher than fathers as a confidante and self-disclosure partner (Buhrmester \& Furman, 1987). The personal nature of many religious and spiritual issues could put the more communicative and intimate parent in the crucial role for discussing religion and thereby serve as "cognitive anchors" (Ozorak, 1989) for the child's spiritual views. We recognize that in some families the father will be the more communicative partner for the child.

Research is beginning to acknowledge the role of religion in fathers' lives and the impact of fathers' religiosity on their parenting (e.g., Dollahite, 1998, 2003). Marks and Dollahite (2001) found that religion may promote greater commitment to children and greater father involvement; religion may strengthen marriage, which, in turn, may promote father involvement. Father involvement is linked with children's positive outcomes (Doherty, Kouneski, \& Erickson, 1998). For many fathers, religious faith plays a central role in their construction of the father role and fosters their involvement (King, 2003; Latshaw, 1998). Involvement in a religious community reduces the likelihood of adolescent boys becoming fathers outside of marriage (Hendricks, Robinson-Brown, \& Gray, 1984).

Other recent work has found that compared to religiously unaffiliated fathers, affiliated fathers are more likely to be engaged with their children (e.g., one-on-one talks) and be involved with youth activities (Wilcox, 2002). On another measure of paternal involvementhaving dinner with one's family-conservative Protestant fathers score higher than unaffiliated fathers (Wilcox, 2002). A study of Jewish families (Herzbrun, 1993) found that fathers who were warmer and communicated more with their adolescents tended to have adolescents who shared their religious views. Dollahite and colleagues have found that religious belief, 
practice, and community are particularly salient in helping fathers of children with special needs meet the ordinary and extraordinary challenges associated with being a parent of such a child (Dollahite, 2003; Dollahite, Marks, \& Olson, 2002; Marks \& Dollahite, 2001).

Siblings represent another potential influence in the religious life of a child's family, but unfortunately this role has been rather ignored. Religious belief and practice can draw families together in challenging times, such as when children pray for their siblings who have disabilities (Marshall, Olsen, Mandelco, Allred, \& Sansom, 2003). We point to research on other, nonreligious topics to suggest that siblings could be important influences on children's religiosity. For example, compared to children without siblings, children with siblings develop a more sophisticated understanding of how people's minds work, for example, how one's beliefs and desires relate to one's behaviors and experiences (Perner, Ruffman, \& Leekam, 1994). Preschoolers with older siblings talk more about mental states than do preschoolers without older siblings, probably because as toddlers they are exposed to more mental-state terms from their older siblings (Jenkins et al., 2003). Because older siblings help younger ones understand the minds of other people, future research should examine whether older siblings seem to help younger ones understand the mind of God and other religious issues. Siblings can offer each other religious and spiritual input and modeling, as well as serve as valuable communication partners who can expand and enrich each other's linguistic maturity and conceptual understanding of spiritual issues. As others have argued (Jenkins et al., 2003), siblings contribute to the amount of talk other children hear in the family about specific topics, and this exposure enhances the children's ability to comprehend and produce such language. This competence then brings the child deeper into the family system's construction of spiritual meaning.

Although our chapter has emphasized parent-child exchange as an engine for spiritual growth, children's beliefs undergo many "secondary adjustments" through so-called thirdparty discussions, and siblings are a major source of such discussions and adjustments (Kuczynski, 2003). These third-party exchanges are probably common in family life and must be studied for a fuller understanding of spiritual growth in children and families.

\section{Conservative Protestant Parenting}

Much empirical work has examined conservative Protestant parents. At the outset it seems fair to say that conservative Protestant parenting is more complicated than some critiques (e.g., Greven, 1990) have suggested. While parents with conservative Protestant affiliations often endorse spanking as a child-rearing technique and feel that it will not harm children (Gershoff, Miller, \& Holden, 1999), they are less likely than other parents to yell at their children (Bartkowski \& Wilcox, 2000) and they typically have a warm, expressive style in nondisciplinary situations (Bartkowski \& Xu, 2000).

Parents' views and behaviors are related not simply to their denominational affiliation but to their endorsement of particular beliefs. For example, theologically conservative ideology (of biblical literalism and fundamentalist beliefs) mediates between parents' denomination and their views and use of corporal punishment (Gershoff et al., 1999). In addition, disciplinary tactics are mediated by the degree to which parents sanctify their role, that is, see parenting as a sacred and holy duty (Mahoney, Pargament, Murray-Swank, \& Murray-Swank, 2003). For example, parents who sanctified their roles and who had more liberal biblical views used less corporal punishment, but corporal punishment by theologically conservative parents was not related to their sanctification of parenting (Murray-Swank, Mahoney, \& Pargament, 2004). Another study found that sanctification of parenting in conservative Christian parents in Appalachia was not related to their endorsement of spanking (Boyatzis \& Tunison, 2002). Together, these studies demonstrate that parents' beliefs are associated with parenting behaviors. Other work has indicated that some parents engage in child-rearing practices that appear to be influenced by their religious faith and that have unhealthy consequences for child development. We now briefly discuss this issue.

\section{Unhealthy Spirituality in Families}

Some forms of family religiosity can distort, misunderstand, or misapply religious teaching in 
ways that are harmful to children. This could include acts done in the name of religion-such as withholding needed medical treatments or forms of spiritual or physical abuse (Mahoney et al., 2003; Silberman, 2003). Arterburn and Felton (2001) offer case studies from ministry and therapy illustrating what they term "toxic faith," the use of religion by parents to "justify" their abusive parenting. Some parents form a "coalition with God" as a disciplinary tactic, threatening children that "God will punish" if they do not obey parents (e.g., Nelsen \& Kroliczak, 1984). In such families, this work has found, children are likely to view God as malevolent.

In addition, some families (perhaps due to influences in their broader culture) promote values that seem inimical to spirituality, including racism, religious bigotry, materialism, consumerism, individualism, and hedonism. Recent work has found that adolescents who highly value financial success and material goods have mothers who were less nurturing than did other adolescents who highly valued relationships and helping the community (Kasser, Ryan, Zax, \& Sameroff, 1995). Related work has shown that adolescents higher in materialism view their parents as less likely to listen to their views or recognize their feelings (Williams, Cox, Hedberg, \& Deci, 2000). Although causality is difficult to establish, these studies indicate that parent-child relationships that appear low in warmth and authenticity are associated with the youth having more hedonistic and self-centered values. In short, these topics become increasingly complex as researchers move from the individual to the familial level of analysis (see Dollahite et al., 2004). In addition, a necessary step to understanding "toxic religion" in families is to have more participant-observer work to balance the typical "outsider" vantage in this research. Qualitative data will illuminate parents' religious beliefs and motivations for child-rearing behaviors that may be deemed by outsiders as unhealthy for their children.

\section{Generative Spirituality}

There has been conceptual and empirical work connecting Erikson's concept of generativity (1982) with spirituality (Dollahite, 2003). Snarey and Dollahite (2001) argue that a generative perspective is uniquely suited to give conceptual coherence to the study of religiosity and family life. A generative approach to spirituality in children and youth can provide scholars with important concepts and processes. One approach is "generative spirituality" (Dollahite et al., 2002; Dollahite, Slife, \& Hawkins, 1998). Generative spirituality is a transcendent connection with the next generation that flows from and encourages convictions of abiding care for that generation.

For many families and family members, religious belief encourages their generative commitment, and religious practice and community support their generative actions. Dollahite et al. (1998) argued that generative action is inherently spiritual because it "involves transcending selfishness, the demands of the present, and the attractions and distractions of one's own generation" (p. 469). Generative spirituality involves adult family members, in concert with others and individually, abiding by their deep convictions to maintain transcendent connections with the next generation. For many families and family members, religious belief, practice, and community encourages generative action, although many generative individuals and families do not define themselves as religious or even spiritual.

There are three aspects of generative spirituality for families: shared spiritual paradigm (common transcendent beliefs), shared spiritual practices (meaningful rituals and traditions), and shared spiritual community (a congregation of care).

Shared Spiritual Paradigm. Pargament (1997) suggested that the essential definition of religion is a process that involves "a search for significance in ways related to the sacred" (p. 32). Eliade's (1959) concept of an axis mundi as adapted by Latshaw (1998) and Marks and Dollahite (2001) relates to the core religious meanings through which a person or family perceives and acts upon the world. For highly religious families, beliefs, practices, and communities serve as the "core worldview" around which other parts of life revolve. Consistent with these assertions, religious parents are likely influenced by their beliefs in how they view 
their parenting, the appropriateness of physical punishment, and the degree of warmth they exhibit toward children (Mahoney et al., 2003).

Shared Spiritual Practices. Several studies have shown a connection between joint religious practices and marital happiness. Mahoney et al. (1999) found that spouses who share involvement in religious activities (praying, attending worship) and who perceived marriage as having a spiritual character also had better functioning across many aspects of marriage (adjustment, less conflict and verbal aggression, greater use of collaborative problem solving).

Shared Spiritual Community. Generative spirituality cannot occur without involvement of parent and child in some larger community. In other words, it takes a faith community to raise a child to generative and spiritual maturity. If a child only has parents and neighbors (a local village, if you will), the child will likely lack a broader community of caring that addresses important issues in a coherent way and enacts a set of beliefs and practices that may help the child become more fully human - that is, connected in a caring way to what is beyond the self.

Generative spirituality, then, focuses on encouraging significant, sustained, and sacred consideration of the needs of the next generation. A spiritual approach to generativity emphasizes the benefits (blessings) of faith to adults and children and to relationships (marital, horizontal, intergenerational). The generative spirituality framework highlights "responsible religion" (i.e., religious beliefs and practices that support intergenerational commitment) and "faithful family life" (i.e., committed marital and parent-child relationships infused with spiritual meaning and transcendence). In sum, generative spirituality is developmental in nature and encourages relational, moral, and spiritual growth over the life span; links psychological variables (e.g., meaning), social variables (e.g., community support), and spiritual factors (e.g., prayer, ritual); focuses on strengthening links between generations; encourages responsible parenting; and generates constructive solutions to intergenerational problems.

Generative spirituality thus focuses on how parents, in concert with others and individually, abide by their convictions to maintain transcendent connections with the next generation. A spiritual dimension can encourage families and adult family members to create connections and convictions that can help them transcend intergenerational distance or conflict. This approach suggests that intergenerational relationships should be viewed as sacred and enduring: sacred because they are singular, related to the holy, highly significant, and, to some extent, capable of helping one transcend the mundane concerns of the self; enduring because they have a boundless quality to them, both in terms of time and importance.

Generative Spirituality and Research on RSD. This section discusses how the construct of generative spirituality might influence research on family and RSD. A generative spirituality approach would involve researchers asking questions such as the following: (a) What are your deepest and strongest spiritual beliefs that pertain to helping your children and youth grow spiritually? (b) In what ways do these beliefs influence your relations with your children? (c) When your child faces challenging circumstances, are there ways you try to help your child develop spiritual resources to address the situation? (d) How has your child influenced you religiously and spiritually? (e) How has your relationship with your child influenced how you have addressed challenges to you as a parent? (f) What kinds of sacrifices have your spiritual or religious beliefs or practices influenced you to make for your child? (g) What sacrifices have you asked your child to make for religious or spiritual reasons?

\section{Conclusions}

The family is probably the most potent influence-for better or for worse- - on children's spiritual and religious development, but we still have much to learn about this context. One, we still know too little about specific mechanisms through which family life influences RSD. For the most part, the extant literature speaks only obliquely to the processes and mechanisms of spiritual growth in families. Two, a more valid conceptualization of the complexity of family interaction and influence is needed. We must 
directly examine the child's active role, including how the child can influence parents' spiritual growth, and measure more precisely the differential contributions of mothers, fathers, and siblings, not to mention extended family members. We suspect all family members play roles, albeit different ones. We cite here a recent provocative finding to illustrate the unique contributions of mothers and fathers: Schoolchildren's willingness to forgive others for their transgressions is related positively to their mothers' modeling of forgiveness at home but, surprisingly, to their fathers' being low on forgiveness and on empathy at home (Denham, Neal, \& Bassett, 2004). Three new topics, designs, and methods must be explored (see Boyatzis \& Newman, 2004, on methodological issues). We have highlighted briefly two of these here-children's religious ritual and unhealthy spirituality in families. We also know too little about the construction and use of shared narratives in family life. Researchers will need to employ qualitative methods to probe the deep structure and meanings of such narratives and to fully explore the generative spirituality as laid out above. To understand the long-term impact of childhood experience in the family, longitudinal designs are needed. Finally, the relative paucity of knowledge about non-Christian families in the United States and families in other parts of the world should compel social scientists to study the diversity of families in many countries. We close by noting that progress in all of these areas will be facilitated by a broader professional recognition and respect among social scientists for the potential power of religion and spirituality in family life and children's development.

\section{REFERENCES}

Acock, A. C., \& Bengston, V. L. (1978). On the relative influence of mothers and fathers: A covariance analysis of political and religious socialization. Journal of Marriage and Family, 40, 519-530.

Anderson, D. A., \& Worthen, D. (1997). Exploring a fourth dimension: Spirituality as a resource for the couple therapist. Journal of Marital and Family Therapy, 23, 3-12.
Arterburn, S., \& Felton, J. (2001). Toxic faith. Colorado Springs, CO: Waterbrook.

Bahr, H. M., \& Bahr, K. S. (1996). A paradigm of family transcendence. Journal of Marriage and the Family, 58, 541-555.

Bandura, A. (2003). On the psychosocial impact and mechanisms of spiritual modeling. International Journal for the Psychology of Religion, 13, 167-174.

Bao, W.-N., Whitbeck, L. B., Hoyt, D., \& Conger, R. C. (1999). Perceived parental acceptance as a moderator of religious transmission among adolescent boys and girls. Journal of Marriage and the Family, 61, 362-374.

Bartkowski, J. P., \& Wilcox, W. B. (2000). Conservative Protestant child discipline: The case of parental yelling. Social Forces, 79, 265-290.

Bartkowski, J. P., \& Xu, X. (2000). Distant patriarchs or expressive dads? The discourse and practice of fathering in conservative Protestant families. Sociological Quarterly, 41, 465-485.

Beaumont, S. L. (2000). Conversational styles of mothers and their preadolescent and middle adolescent daughters. Merrill-Palmer Quarterly, 46, 119-139.

Benson P. L., \& Eklin, C. H. (1990). Effective Christian education: A national study of Protestant congregations: A summary on faith, loyalty, and congregational life. Minneapolis, MN: Search Institute.

Boyatzis, C. J. (2003). Religious and spiritual development: An introduction. Review of Religious Research, 44, 213-219.

Boyatzis, C. J. (2004). The co-construction of spiritual meaning in parent-child communication. In D. Ratcliff (Ed.), Children's spirituality: Christian perspectives, research, and applications (pp. 182-200). Eugene, OR: Wipf \& Stock.

Boyatzis, C. J. (in press). Socialization and cognitive processes in children's religious development: Where we have been, where we must go. In R. F. Paloutzian \& C. L. Park (Eds.), The handbook of the psychology of religion. New York: Guilford.

Boyatzis, C. J., \& Janicki, D. (2003). Parent-child communication about religion: Survey and diary data on unilateral transmission and bi-directional reciprocity styles. Review of Religious Research, 44, 252-270. 
Boyatzis, C. J., \& Newman, B. (2004). How shall we study children's spirituality? In D. Ratcliff (Ed.), Children's spirituality: Christian perspectives, research, and applications (pp. 166-181). Eugene, OR: Wipf \& Stock.

Boyatzis, C. J., \& Tunison, S. (2002, August). Religiosity and interpersonal aggression and corporal punishment in Appalachian parents and children. Paper presented at the annual meeting of the American Psychological Association, Chicago.

Brodsky, A. E. (2000). The role of religion in the lives of resilient, urban, African American, single mothers. Journal of Community Psychology, 28, 199-219.

Brody, G. H., Stoneman, Z., \& Flor, D. (1996). Parental religiosity, family processes, and youth competence in rural, two-parent African American families. Developmental Psychology, 32, 696-706.

Buhrmester, D., \& Furman, W. (1987). The development of companionship and intimacy. Child Development, 58, 1101-1113.

Bunge, M. J. (Ed.). (2001). The child in Christian thought. Grand Rapids, MI: Eerdmans.

Cornwall, M. (1987). The social bases of religion: A study of factors influencing religious belief and commitment. Review of Religious Research, 29, 44-56.

DeLoache, J., \& Gottlieb, A. (2000). A world of babies: Imagined childcare guides for seven societies. Cambridge, UK: Cambridge University Press.

Denham, S. A., Neal, K., \& Bassett, H. H. (2004, April). "You hurt my feelings pretty bad": Parents' and children's emotions as contributors to the development of forgiveness. Paper presented at the biennial Conference on Human Development, Washington, DC.

Doherty, W. J., Kouneski, E. F., \& Erickson, M. F. (1998). Responsible fathering: An overview and conceptual framework. Journal of Marriage and the Family, 60, 277-292.

Dollahite, D. C. (1998). Origins and highlights of the special issue on fathering, faith, and spirituality. Journal of Men's Studies, 7, 1-2.

Dollahite, D. C. (2003). Fathering for eternity: Generative spirituality in Latter-day Saint fathers of children with special needs. Review of Religious Research, 44, 237-251.
Dollahite, D. C., \& Clifton, C. (2005). Religion as source of identity, purpose, connection, and strength in Jewish, Christian, Muslim, and Mormon youth. Unpublished manuscript.

Dollahite, D. C., \& Marks, L. D. (2005). How highly religious families strive to fulfill sacred purposes. In V. L. Bengtson, D. Klein, A. Acock, K. Allen, \& P. Dilworth-Anderson (Eds.), Sourcebook of family theory and research (pp. 533-537). Thousand Oaks, CA: Sage.

Dollahite, D. C., Marks, L. D., \& Goodman, M. (2004). Families and religious beliefs, practices, and communities: Linkages in a diverse and dynamic cultural context. In M. J. Coleman \& L. H. Ganong (Eds.), The handbook of contemporary families: Considering the past, contemplating the future (pp.411-431). Thousand Oaks, CA: Sage.

Dollahite, D. C., Marks, L. D., \& Olson, M. M. (2002). Fathering, faith, and family therapy: Generative narrative therapy with religious fathers. Journal of Family Psychotherapy, 13, 263-294.

Dollahite, D. C., Slife, B. D., \& Hawkins, A. J. (1998). Family generativity and generative counseling: Helping families keep faith with the next generation. In D. P. McAdams \& E. de St. Aubin (Eds.), Generativity and adult development: How and why we care for the next generation (pp. 449-481). Washington, DC: American Psychological Association.

Dudley, R. L., \& Dudley, M. (1986). Transmission of religious values from parents to adolescents. Review of Religious Research, 28, 3-15.

Dudley, R. L., \& Wisbey, R. L. (2000). The relationship of parenting styles to commitment to the church among young adults. Religious Education, 95, 39-50.

Durkheim, E. (1951). Suicide. Glencoe, IL: Free Press. (Original work published 1897)

Eliade, M. (1959). The sacred and the profane: The nature of religion. New York: Harcourt Brace Jovanovich.

Erikson, E. H. (1982). Identity and the life cycle. New York: Norton.

Evans, E. M. (2000). Beyond Scopes: Why creationism is here to stay. In K. S. Rosengren, C. N. Johnson, \& P. L. Harris (Eds.), Imagining the impossible: Magical, scientific, and religious thinking in children (pp. 305-333). Cambridge, UK: Cambridge University Press. 
Flor, D. L., \& Knapp, N. F. (2001). Transmission and transaction: Predicting adolescents' internalization of parental religious values. Journal of Family Psychology, 15, 627-645.

Fowler, J. (1981). Stages of faith: The psychology of human development and the quest for meaning. New York: HarperCollins.

Francis, L. J., \& Brown, L. B. (1990). The predisposition to pray: A study of the social influence on the predisposition to pray among eleven-yearold children in England. Journal of Empirical Theology, 3, 23-34.

Francis, L. J., \& Brown, L. B. (1991). The influence of home, church and school on prayer among sixteen-year-old adolescents in England. Review of Religious Research, 33, 112-122.

Francis, L. J., \& Gibson, H. M. (1993). Parental influence and adolescent religiosity: A study of church attendance and attitude toward Christianity among adolescents 11 to 12 and 15 to 16 years old. International Journal for the Psychology of Religion, 3, 241-253.

Gallup, G., Jr., \& Castelli, J. (1989). The people's religion. New York: Macmillan.

Gershoff, E. T., Miller, P. C., \& Holden, G. W. (1999). Parenting influences from the pulpit: Religious affiliation as a determinant of corporal punishment. Journal of Family Psychology, 13, 307-320.

Greven, P. (1990). Spare the child: The religious roots of punishment and the psychological impact of physical abuse. New York: Vintage Books.

Gunnoe, M. L., Hetherington, E. M., \& Reiss, D. (1999). Parental religiosity, parenting style, and adolescent social responsibility. Journal of Early Adolescence, 19, 199-225.

Heller, D. (1986). The children's God. Chicago: University of Chicago Press.

Hendricks, L. E., Robinson-Brown, D. P., \& Gray, L. E. (1984). Religiosity and unmarried black adolescent fatherhood. Adolescence, 19, 417-424.

Herzbrun, M. B. (1993). Father-adolescent religious consensus in the Jewish community: A preliminary report. Journal for the Scientific Study of Religion, 32, 163-168.

Hoge, D. R., Petrillo, G. H., \& Smith, E. I. (1982). Transmission of religious and social values from parents to teenage children. Journal of Marriage and the Family, 44, 569-580.

Hunsberger, B., \& Brown, L. B. (1984). Religious socialization, apostasy, and the impact of family background. Journal for the Scientific Study of Religion, 23, 239-251.

James, W. (1986). The varieties of religious experience. New York: Penguin. (Original work published 1902)

Jenkins, J. M., Turrell, S. L., Kogushi, Y., Lollis, S., \& Ross, H. S. (2003). A longitudinal investigation of the dynamics of mental state talk in families. Child Development, 74, 905-920.

Kasser, T., Ryan, R. M., Zax, M., \& Sameroff, A. J. (1995). The relations of maternal and social environments to late adolescents' materialistic and prosocial values. Developmental Psychology, 31, 907-914.

King, V. (2003). The influence of religion on fathers' relationships with their children. Journal of Marriage and the Family, 65, 382-395.

King, P. E., Furrow, J. L., \& Roth, N. (2002). The influence of families and peers on adolescent religiousness. Journal of Psychology and Christianity, 21, 109-120.

Kuczynski, L. (2003). Beyond bidirectionality: Bilateral conceptual frameworks for understanding dynamics in parent-child relations. In L. Kuczynski (Ed.), Handbook of dynamics in parent-child relations (pp.3-24). Thousand Oaks, CA: Sage.

Kuebli, J., Butler, S., \& Fivush, R. (1995). Motherchild talk about past emotions: Relations of maternal language and child gender over time. Cognition and Emotion, 9, 265-283.

Latshaw, J. S. (1998). The centrality of faith in father's role construction: The faithful father and the axis mundi paradigm. Journal of Men's Studies, 7, 53-70.

Leaper, C., Anderson, K. J., \& Sanders, P. (1998). Moderators of gender effects on parents' talk to their children: A meta-analysis. Developmental Psychology, 34, 3-27.

Mahoney, A., Pargament, K. I., Jewell, T., Swank, A. B., Scott, E., Emery, E., et al. (1999). Marriage and the spiritual realm: The role of proximal and distal religious constructs in marital functioning. Journal of Family Psychology, 13, 321-338.

Mahoney, A., Pargament, K. I., Murray-Swank, A., \& Murray-Swank, N. (2003). Religion and the sanctification of family relationships. Review of Religious Research, 44, 220-236.

Mahoney, A., Pargament, K. I., Swank, A., \& Tarakeshwar, N. (2001). Religion in the home 
in the 1980s and 90s: A meta-analytic review and conceptual analysis of religion. Journal of Family Psychology, 15, 559-596.

Marks, L. D. (2004). Sacred practices in highly religious families: Christian, Jewish, Mormon, and Muslim perspectives. Family Process, 43, 217-231.

Marks, L. D., \& Dollahite, D. C. (2001). Religion, relationships, and responsible fathering in Latterday Saint families of children with special needs. Journal of Social and Personal Relationships, 18, 625-650.

Marshall, E. S., Olsen, S. F., Mandelco, B. L., Allred, K. W., \& Sansom, N. (2003). "This is a spiritual experience": Perspectives of Latter-Day Saint children with disabilities. Qualitative Health Research, 13, 57-76.

Miller, W. R., \& Thoresen, C. E. (2003). Spirituality, religion, and health: An emerging research field. American Psychologist, 58, 24-35.

Murray-Swank, A. B., Mahoney, A., \& Pargament, K. I. (2004). Sanctification of parenting: Links to corporal punishment and parental warmth among biblically conservative and liberal mothers. Manuscript submitted for publication.

Nelsen, H. M. (1990). The religious identification of children of interfaith marriages. Review of Religious Research, 32, 122-134.

Nelsen, H. M., \& Kroliczak, A. (1984). Parental use of the threat "God will punish": Replication and extension. Journal for the Scientific Study of Religion, 23, 267-277.

Okagaki, L., \& Bevis, C. (1999). Transmission of religious values: Relations between parents and daughters' beliefs. Journal of Genetic Psychology, 160, 303-318.

Ozorak, E. W. (1989). Social and cognitive influences on the development of religious beliefs and commitment in adolescence. Journal for the Scientific Study of Religion, 28, 448-463.

Pargament, K. I. (1997). The psychology of religion and coping. New York: Guilford.

Parker, M., \& Gaier, E. L. (1980). Religion, religious beliefs, and religious practices among Conservative Jewish adolescents. Adolescence, 15, 361-374.
Perner, J., Ruffman, T., \& Leekam, S. R. (1994). Theory of mind is contagious: You catch it from your sibs. Child Development, 65, 1228-1238.

Regnerus, M. D. (2003). Linked lives, faith, and behavior: Intergenerational religious influence on adolescent delinquency. Journal for the Scientific Study of Religion, 42(2), 189-203.

Richards, P. S., \& Bergin, A. E. (1997). A spiritual strategy for counseling and psychotherapy. Washington, DC: American Psychological Association.

Rizzuto, A.-M. (1979). The birth of the living God: A psychoanalytic study. Chicago: University of Chicago Press.

Silberman, C. E. (1985). A certain people: American Jews and their lives today. New York: Summit.

Silberman, I. (2003). Spiritual role modeling: The teaching of meaning systems. International Journal for the Psychology of Religion, 13, 175-195.

Snarey, J. R., \& Dollahite, D. C. (2001). Varieties of religion-family linkages. Journal of Family Psychology, 15, 646-651.

Spilka, B., Hood, R. W., Jr., Hunsberger, B., \& Gorsuch, R. (2003). The psychology of religion: An empirical approach (3rd ed.). New York: Guilford.

Strommen, M. P., \& Hardel, R. A. (2000). Passing on the faith: A radical new model for youth and family ministry. Winona, MN: Saint Mary's Press.

Vygotsky, L. S. (1978). Mind in society. Cambridge, MA: Harvard University Press.

Walker, L. J., \& Taylor, J. H. (1991). Family interaction and the development of moral reasoning. Child Development, 62, 264-283.

Wilcox, W. B. (2002). Religion, convention, and paternal involvement. Journal of Marriage and Family, 64, 780-792.

Williams, G. C., Cox, E. M., Hedberg, V. A., \& Deci, E. L. (2000). Extrinsic life goals and health risk behaviors in adolescents. Journal of Applied Social Psychology, 30, 1756-1771.

Wuthnow, R. (1999). Growing up religious: Christians and Jews and their journeys of faith. Boston: Beacon. 